\title{
Article
}

\section{Macroscopic Structure Change and Optical Anisotropy Induced by Yield Behavior of Clay Dispersing Colloidal Gels}

\author{
Ippei Homma ${ }^{*}$, Tsutomu TAKAHASHI ${ }^{* * \dagger}$, Kenji NodA ${ }^{* * *}$, Tomoko SeKINE ${ }^{* * *}$, \\ Masaki KitaJima $^{* * *}$ and Atsushi Sogabe ${ }^{* * *}$ \\ * Department of Energy and Environment Science, Graduate School of Nagaoka University of Technology, \\ 1608-1 Kamitomioka, Nagaoka, Niigata 940-2188, Japan \\ ** Department of Mechanical Engineering, Nagaoka University of Technology, \\ 1608-1 Kamitomioka, Nagaoka, Niigata 940-2188, Japan \\ ${ }^{* * *}$ Shiseido Research Center, 2-2-1 Hayabuchi, Tuduki-ku, Yokohama, Kanagawa 224-8558, Japan
}

\begin{abstract}
The relationship between the yield like behaviors and macroscopic and microscopic structures of the colloidal gels, which are consisted by silicone oil, hectorite and PEO, are examined from the rheological property, the anisotropic optical property and the flow behavior. These colloidal gels exhibit the yield behaviors in the stress ramp test and another yield like behavior is also observed in the high shear regime. From the motion of the oil droplets observed by the high-speed microscope and result of the flow birefringence measurements, the occurrence of the first yield behavior would be caused by generation of the thin shear layer and the other layers do not change their macroscopic structure for a while. During the flow after the first yield behavior, some part of the sample in the flow field becomes viscous thickening suddenly and it causes a large-scale flow fluctuation. The high viscosity region spreads to a whole area and a whoop stress appears. In this state, the flow birefringence shows the similar behavior of the polymer fluids. Therefore, we thought that the macroscopic structure related to the second yield behavior includes the entanglement like polymer fluids.
\end{abstract}

Key Words: Colloidal gel / Yield behavior / Rheo-Optic measurement / Direct visualization / Microscopic observation

\section{粘土コロイド分散系ゲルの降伏挙動に伴う光学異方性の発現と巨視的構造変化}

\section{本間 一平 ${ }^{*}$, 高橋 勉 ${ }^{* *} \dagger$, 野田 賢二***, 関根 知子**, 北島 正樹 ${ }^{* * *}$, 曽我部 敦***}

(原稿受理：2017 年 8 月 30 日)

\section{1. 緒 言}

粘土鉱物は地球上に豊富に存在し安価であること, 膨潤性, 吸着性, イオン交換性, 分散・凝集・剥離など多様な特性を 持つことから, 工業的利用として化粧品や文房具製品, 農薬, 医薬など極めて広い分野で取り扱われる。特に化粧品分野で は天然素材であることや污れを吸着すること, 粘土粒子の相 互作用で増粘化することなどの理由によって多く用いられて 抢り，スキンケアクリームなどの製品を構成する素材の中で 粘土鉱物は非常に重要な役割を果たしている で膨潤性が良くゲル化するスメクタイトは乳液・クリームな どの基材の多くに含まれている2．スメクタイトによるゲル は肌に塗布した際のぬめりや乾いた後のべたつきがないこと や，高分子ゲルにはない良好な使用感を持つことが, 化粧品

† E-mail : ttaka@nagaokaut.ac.jp, Tel : 0258-47-1611-(9728)

* 長岡技術科学大学 大学院 工学系研究科 エネルギー・環境工学専攻

下940-2188 新潟県長岡市上富岡町1603-1

** 長岡技術科学大学 大学院 技学研究院 機械創造工学専攻

†940-2188 新潟県長岡市上富岡町 1603-1

*** 資生堂リサーチセンター

干224-8558 神奈川県横浜市都筑区早㴊 2-2-1
としての大きなアドバンテージとなっている.

粘土については古くから研究されており，その分野は基礎 となる粘土鉱物の結晶構造的研究からコロイドなどの応用研 究まで多岐にわたっている. スメクタイト族に属するへクト ライトは主成分であるモンモリロナイトの構造が基本となる。 モンモリロナイトは層間にナトリウムイオンやカルシウムイ オンなどの交換性のカチオンが存在する層状構造になってい る ${ }^{2)}$ （モンモリロナイトの層間にある交換性カチオンを四級 アンモニウムイオンや非イオン界面活性剂に交換する有機変 性処理を行うことで，水には膨潤せずに溶剤系で膨潤・ゲル 化作用を示すようになる。 さらに, 非イオン界面活性剤の種 類や量を変えることにより粘度を調整できることが知られて いる。 また，四級アンモニウムイオンで交換した有機変性モ ンモリロナイトに，ささらに非イオン界面活性剤を包接させた 場合に包接力の強い非イオン界面活性剂ほど，より強固な油 性ゲルを形成する 2 2-5).

このようなゲルは重力下でも巨視的な形状を保持する程度 の弱い構造を持つことが知られている，静置状態のゲルにあ る大きさ以上の力を加えるとその形状が崩机粘度が急低下し 流動を開始するという塑性的挙動を示す。これは固体に打け 
る降伏現象と似ているが, 粘弾性的特性やゲル構造の形成メ カニズムの複雑さや，流動停止により再構造化するなどと いった要因からその挙動は非常に複雑である。ビンガム流体 は降伏挙動を示す流体として知られており，降伏応力は物性 值として定義することができる。しかし実際にはクリームな ど弱い降伏力を有するソフトマターに打降伏挙動は, 応 力を印加する時間や速度などといったさまざまな因子から影 響を受ける複雑な現象である。たとえば降伏応力以下のせん 断応力を長時間印加することで降伏挙動が発生する可能性も あり，ステップせん断流動で一定の応力を印加するなどの一 般的な手法からだけでは降伏挙動を正しく把握することは難 しい.

化粧品として肌に塗布した際は人間の敏感な感覚がこのよ うな複雑な挙動を感じ取るため, 降伏挙動は使用感に重要な 影響を与えている。一例として降伏挙動や, 変形により粘度 が低下するチクソトロピー性を有する製品は伸びがよく良好 な使用感を持つとされることが報告されており ${ }^{0}$, 機能性の 高い製品開発のため降伏挙動を含む流動現象の解明が急がれ ている. 物質の力と変形の関係を定量的に評価するレオロ ジーは製品の使用感を評価する上で有効なアプローチであり， 近年, 化粧品等の使用感をレオロジーから評価する研究が増 加している7). また, 化粧品に限らずクリームやゲル, サス ペンションなど広い分野の製品に広く利用されるソフトマ ターの降伏挙動や流動特性についての研究報告は少なくな ( ${ }^{8-18)}$. しかしながら, 現状では組成の化学的効果にのみ注 目されており, 使用感に繋がる力学的特性の関係や降伏前後 の構造の変化, 再構造化のメカニズムなどについては研究が 進んでいない.

本研究では，シリコーンオイルに粘土粒子と界面活性剂を 分散して形成したコロイドゲルにおける降伏を含む流動挙動 とそれに伴う巨視的・微視的な構造変化を解明することを目 的とし実験 - 考察を行う. 応力増加試験を実施し, 応力の増 加に対するひずみの応答を整理することで降伏挙動を評価す る. さらに, 応力増加試験と同時に流動複屈折を測定するレ オ・オプティック測定を行い, 降伏挙動とそれに伴う微視的 構造の関係を明らかとする。 また応力増加試験と同時に流路
内の試料全体をデジタルカメラにより撮影する外観観察や, 光学顕微鏡を用いた一定のせん断速度で流動中の試料の観察 を行い, 巨視的な構造変化と降伏現象の解明を明らかにする。

\section{2. 実験装置, 方法および試料}

\section{1 使用試料}

分散媒に揮発性シリコーンオイル，分散質に有機変成へク トライト（粒子の平均的形状：縦横 $8 \sim 80 \mathrm{~nm}$, 厚さ 1〜 $3 \mathrm{~nm}$ の平板状), 高分子溶質および界面活性剂の役割として ポリエチレンオキサイド（PEO）を添加しゲル化させた粘土 コロイド分散系ゲルを使用した。覺拌方法とへクトライトお よび PEOの重量濃度を変えた 6 種類の試料を Table 1 に示す. 攪挥方法の違いについては，材料を混合しただけのものを通 常分散，その後さらにビーズミルにより細かく攪拌・分散し たものを高分散とよぶ. これ以降, 試料の呼称を通常分散の ものを「(ヘクトライト濃度)：(PEO 濃度) ゲル」と標記し， 高分散処理したものにはその頭に「H」を付けて標記する. Fig. 1 に各試料を光学顕微鏡で観察した写真を示す。通常分 散においては，6：12 ゲルでは針状の析出物が観察され, 6:6ゲルでは粘土粒子の凝集体が黒い塊となって現れてい る. $8: 8$ ゲルは凝集体がかなり小さくなり, きめ細かいテ クスチャを形成している。H8：16 ゲルでは通常分散 6：12 ゲルと同ような針状の析出物がみられた。また H8: 4 ゲル,

Table 1 Sample name and weight concentration of Hectorite and PEO.

\begin{tabular}{|c|c|c|}
\hline Sample Name & $\begin{array}{c}\text { Hectorite } \\
\mathrm{wt} \%\end{array}$ & $\begin{array}{c}\text { PEO } \\
\mathrm{wt} \%\end{array}$ \\
\hline $6: 12$ gel & 6 & 12 \\
\hline $6: 6$ gel & 6 & 6 \\
\hline $8: 8$ gel & 8 & 8 \\
\hline H8 $: 16$ gel & 8 & 16 \\
\hline H8 $: 8$ gel & 8 & 8 \\
\hline H8 $: 4$ gel & 8 & 4 \\
\hline
\end{tabular}
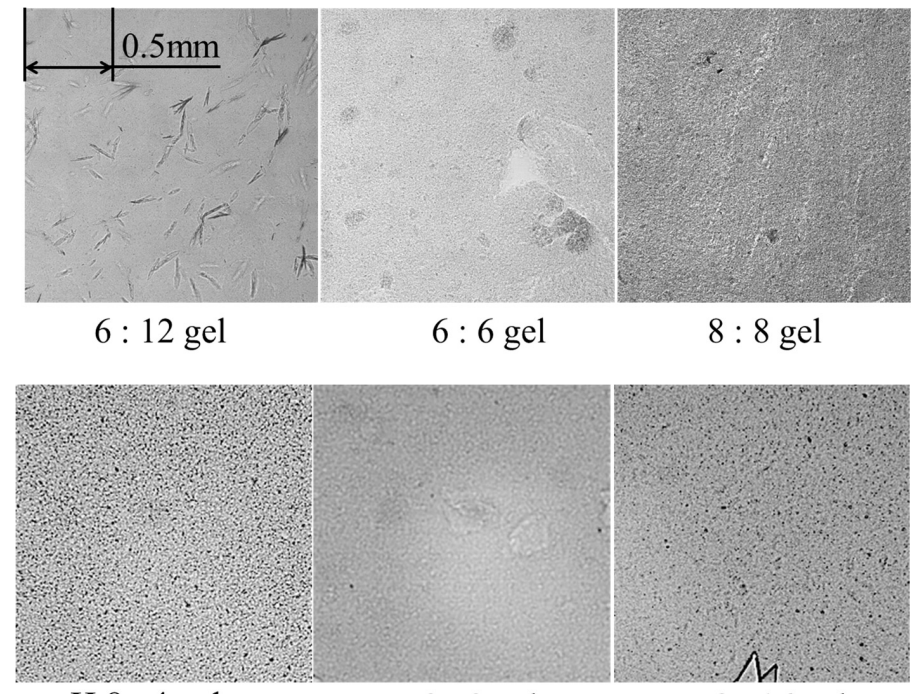
H $8: 4$ gel
H $8: 8$ gel
H $8: 16$ gel

Fig. 1 Samples observed by optical microscope. 
$\mathrm{H} 8: 8$ ゲルどちらも 10 ミクロン以下の小さな凝集体はみら れるものの通常分散ゲルのような大きな塊はみられない.す

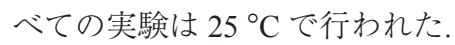

\section{2 レオメータ}

応力増加試験など主なレオロジー測定のプラットフォーム として応力制御型レオメータである MCR301 (Anton Paar 社）を用いた。流路には光学ガラス製の平行円板流路を使用 した。 円板の直径は $43 \mathrm{~mm}$ であり, 流路間隙は $0.1 \mathrm{~mm}$ とし た。平行円板流路は上部円板が回転し，下部円板は静止して いる.

\section{3 降伏挙動の評価}

Fig. 2 に通常分散 $8: 8$ ゲルに対して応力増加試験を実施 した結果を応力ひずみ線図として評価した結果を示す。せん 断応力 $\tau$ をゼロから最大印加応力 $\tau_{\text {max }}=400 \mathrm{~Pa}$ まで応力増加 率 $d \tau / d t$ が一定值 $2 \mathrm{~Pa} / \mathrm{s}$ となるように増加させた. Fig. 2 に示 すように，まず $\tau \fallingdotseq 45 \mathrm{~Pa}$ で曲線の傾きが水平方向に急に変 化する点がみられた，本報告では応力ひずみ線図においてこ のように応力の増加量に対してひずみが急激に増加する点, すなわち曲線の傾きが不連続に小さくなる点を降伏点と見な す. 具体的には降伏点発生前後の応力ひずみ曲線を 1 次式で 近似し, これら 2 つ直線が交差する点を降伏点と定義した. また, $\tau \doteqdot 45 \mathrm{~Pa} て ゙$ 降伏的挙動が発生したのち, $\tau \doteqdot 70 \mathrm{~Pa}$ で曲 線の傾きの值が増加し, $\tau \doteqdot 180 \mathrm{~Pa}$ で再び降伏的挙動が発生 している。このように応力増加試験において観察された $2 つ$ の降伏挙動を低応力側から第 1 降伏挙動, 第 2 降伏挙動, ま

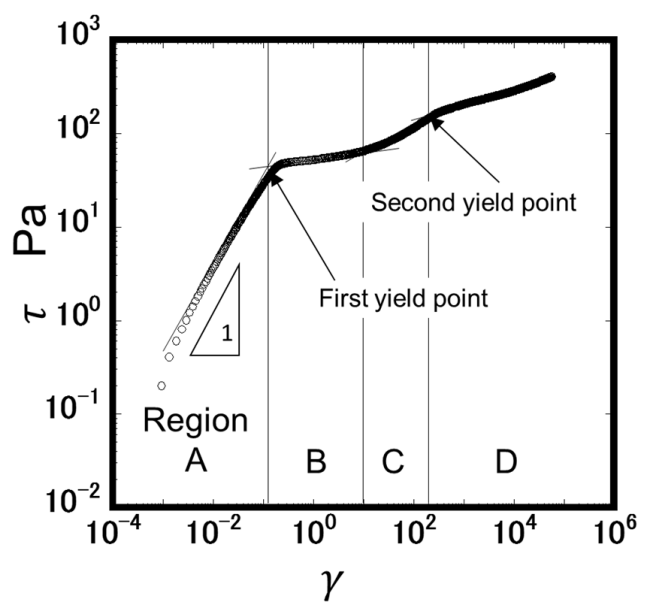

Fig. 2 Stress-Strain curve of $8: 8$ gel.

Table 2 Yield stresses of each samples.

\begin{tabular}{|c|c|c|}
\hline Sample Name & $\begin{array}{c}\text { First Yield Stress } \\
\text { Pa }\end{array}$ & $\begin{array}{c}\text { Second Yield Stress } \\
\text { Pa }\end{array}$ \\
\hline $6: 12$ gel & 4 & - \\
\hline $6: 6$ gel & 20 & 60 \\
\hline $8: 8$ gel & 45 & 180 \\
\hline H8:16 gel & 2.5 & - \\
\hline H8 $: 8$ gel & 1.2 & 15 \\
\hline H8 $: 4$ gel & 3.8 & 30 \\
\hline
\end{tabular}

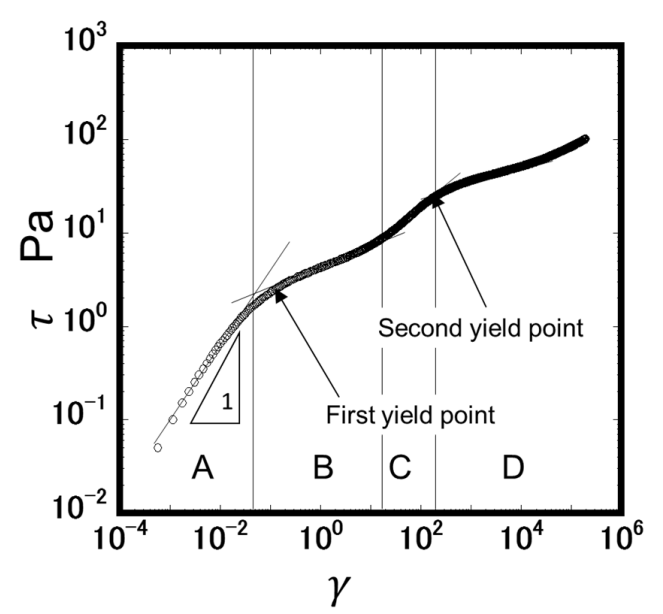

Fig. 3 Stress-Strain curve of H8 : 8 gel.

たそれぞれの降伏点を第 1 降伏点, 第 2 降伏点とよぶ. また, 2 つの降伏挙動および粘度増加挙動を整理するために応力ひ ずみ線図を 4 つに領域分けした。流動開始から第 1 降伏点ま でを領域 A，グラフの傾きが増加するまでを領域 B，第 2 降 伏点までを領域 $\mathrm{C}$, そして第 2 降伏点以降を領域 D と定義 する. Table 2 に応力増加試験から求めた各試料の第 1 降伏 応力, 第 2 降伏応力の值を示す。降伏挙動が発生しない試料 については「ー」で表記している. Fig. 3 に $\mathrm{H} 8$ ：8 ゲルの応 力ひずみ線図を示す。配合割合が同じである $8: 8$ ゲルと H8：8 ゲルを比較すると, 通常分散に比べ高分散処理を行っ た H8：8 ゲルでは降伏応力が第 1 , 第 2 降伏ともに大きく低 下する。通常分散では Fig. 1 の顕微鏡写真でわかるサイズの 凝集体が多数存在し，ゲルにより結合したサブミクロンサイ ズの油滴も大きなクラスター構造を形成している。これらの 影響で高い降伏強度を持つ反面, 降伏值の再現性は良好とは 言えない.一方で高分散処理を行った試料は，機械的に細か く攪汼・分散処理を行うため凝集体はほとんど観察されず, 大きなクラスター構造体も形成しない。試料全体にわたり均 質な分散状態が形成されており降伏応力が低く, 測定におけ る再現性は通常分散に比べて高い.

\section{4 レオ・オプティック測定}

力学的挙動と微視的構造の関係を知るためにレオロジー特 性と流動複屈折を同時測定する手法, レオ・オプティック測 定を行った。レオメータに複屈折測定ユニットを取り付け, レオメータと同期して測定するシステムを構築した. Fig. 4 にレオ・オプティック測定装置の概略図を示す。流動複屈折 測定には偏光変調方式として回転半波長板型を用いた ${ }^{19)}$. 光 源は波長 $632.8 \mathrm{~nm}$, ビーム直径 $0.8 \mathrm{~mm}$, 出力 $5 \mathrm{~mW}$ の $\mathrm{He}-\mathrm{Ne}$ レーザである，偏光変調器（PSG）により偏光方向が 時間的に変化する直線偏光に変調し，流路に垂直に照射する， 試料を通過した光は偏光解析器 (PSA) である円偏光板を経 て受光器に入射し, 透過光の光強度の時間変化を解析するこ とで試料の流動複屈折が評価される. 光路長は平行円板流路 の流路間隙，すなわち $0.1 \mathrm{~mm}$ である。レオ・オプティック 測定には主に通常分散 $6: 12$ ゲル, $6: 6$ ゲル, $8: 8$ ゲルの 3 つの試料を用いた。これは, 高分散試料に比べ通常分散試 料では顕微鏡写真でみられた試料の配合割合ごとの特性がよ り明確であるためである。 


\section{5 光学顕微鏡観察}

ゲルを構成する油滴の挙動の観察を目的に, 数〜数百ミク ロン・オーダーの構造を観察できる高速度光学顕微鏡観察を 行った. Fig. 5 にせん断流動顕微鏡観察に用いた可視化装置 の概略を示す。せん断流動の形成にはせん断可視化装置 CSS450（Lincam 社）を使用した。 2 枚のガラスプレートの 間に試料を挟み，下側のガラスプレートを回転させることで 試料に一定せん断速度のせん断流動を与え, その様子を光学 顕微鏡 BX-50（オリンパス社）に取りつけたハイスピードカ メラ（フォトロン社）で撮影する。顕微鏡のピントは上側

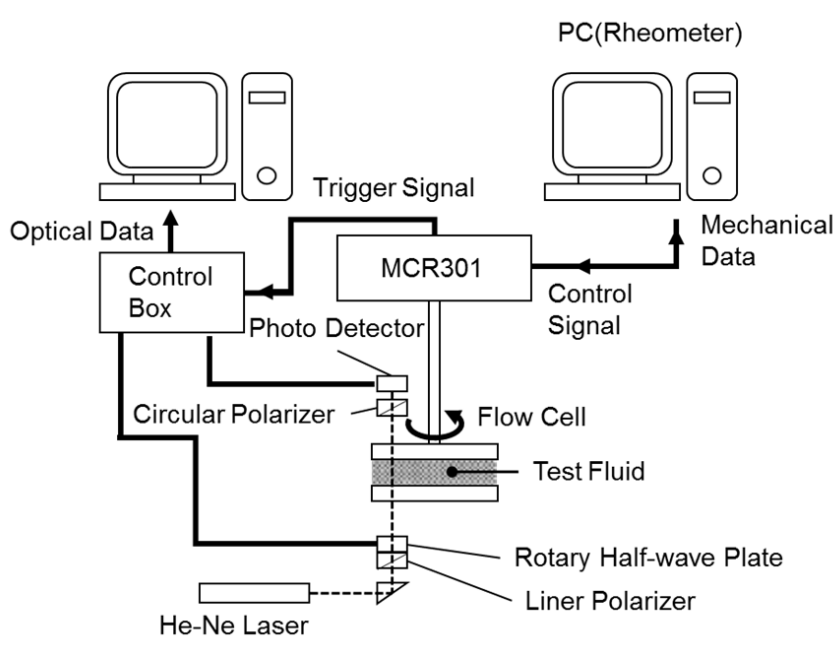

Fig. 4 Schematic diagram of Rheo-Optic measurements system.

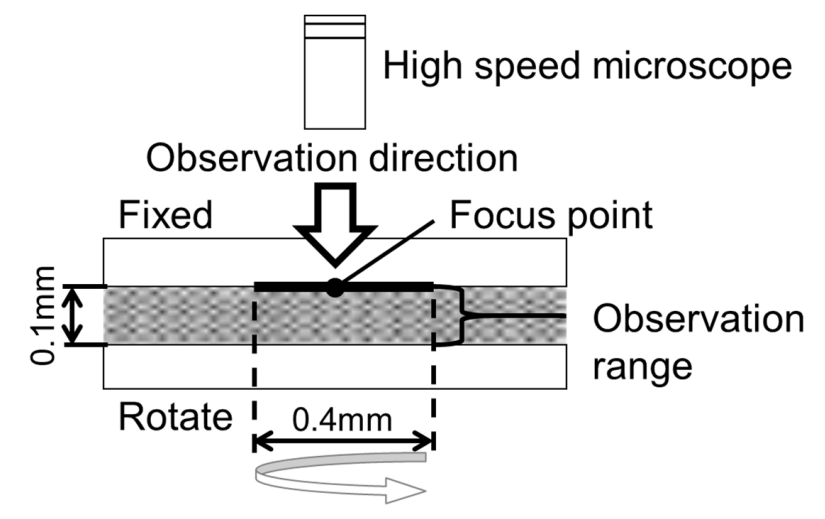

Fig. 5 Schematic diagram of microscopic observation.
(静止側) のガラスプレートとサンプルの固液界面に合わせ る。流路間隙は $0.1 \mathrm{~mm}$ とし, 試料は比較的テクスチャや粒 子の動きを捉えやすい高分散試料である H8：4 ゲルを用い た.

\section{6 外観観察}

外観観察の概略図と撮影によって得られた写真の一例を Fig. 6 に示す。レオメータにガラス製平行円板流路を取りつ け，下面に設置したデジタルカメラにより流れ場全体を観察 した。試料は通常の測定とは異なり平行円板間全体に満たさ れるように充填せず，上部円板の外周から内側に $2 \mathrm{~mm}$ の空 間が空くように充填する。そして試料と空気の界面である試 料の輪郭線の形の変化を撮影した. 応力増加率 $d \tau / d t=0.5$ $\mathrm{Pa} / \mathrm{s}$, 最大印加応力 $\tau_{\max }=100 \mathrm{~Pa}$ と設定した応力増加試験の 実施中について外観観察を行った。流路間隙は $0.1 \mathrm{~mm}$ とし た。隙間が狭いことから，試料厚さ方向の影響を排除した 2 次元的な輪郭線の変化が観察できる。外観観察には第 2 降伏 挙動が発生する高分散試料 H8：8 ゲルと, 第 2 降伏挙動が 発生しない高分散試料 H8：16 ゲルを用いた。傾向をできる 限り詳細に検討するため, 再現性の良い高分散試料を用いて いる.

\section{3. 実験結果および考察}

\section{1 レオ・オプティック測定による微視的構造変化の評価}

Table 1 に示したように粘土と PEO の濃度により第 2 降伏 挙動が発生する試料としない試料に分類した. Fig. 1 に示す 各試料の静止状態の光学顕微鏡写真では構造的な特徵が観察 できるが，降伏挙動の関連性はわからない，そこで，微視的 な異方性や配向状態の時間的変化を感知する方法として流動 複屈折の評価を行う. 流動複屈折には $\mu \mathrm{m}$ オーダーの構造 に起因する形状効果と分子構造に起因する固有効果がある. 計測された複屈折の数值からはどちらの効果が発現したもの か判断することは難しいが，後述する高速度顕微鏡観察や流 れ場全体の画像より形状効果を誘起するような構造形成は観 察されなかったことから，ここで示す結果はゲルの伸縮，配 向に起因する固有効果が主として観察されたと考える.

Fig. 7 およびFig. 8 に 6:6 ゲル, $8: 8$ ゲルの応力増加試 験中の複屈折の時間的変化を示す。これらの結果に関しては 応力ひずみ線図と同様の方法から領域を 4 つに分け結果を整 理している。どちらの試料においても第 1 降伏が発生した瞬 間に複屈折が急低下する。これらの試料は $6: 12$ ゲルに比べ

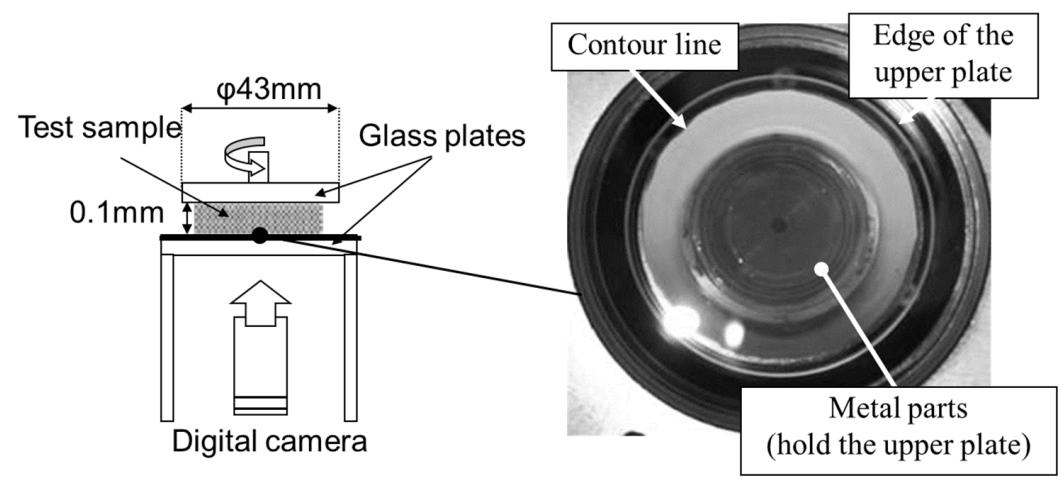

Fig. 6 Experimental setup of contour line visualization. 
て静置状態でその形状を保持できる程度に固い.たとえばボ トルに入れた状態で静置しその後にボトルを倒しても流動せ ずに形を維持する程度に結合力が強い.このため第 1 降伏応 力は 6：12 ゲルよりもかなり高い值となる (Table 2 参照). 第 1 降伏挙動は試料全体の平均的な変形からせん断層の形成 による局所的な大変形に至る過程と考えられる。したがって せん断層が形成されて突然大変形のひずみが発生しレオメー 夕の動きが追いつかない一瞬の応力の緩和が複屈折の現象と して測定されたと推測される。その後, 領域 B，Cにおいて 複屈折が増加し第 2 降伏発生時に再び低い值となる. $8: 8$ ゲルでは領域 B から C の間で複屈折が大きく増加し極大值 を経た後に低下する現象も見られた．Fig. 9 に高分散試料の レオ・オプティック測定の一例として H8：8 ゲルの応力増 加試験中の複屈折の時間的変化を示す. 高分散試料でも通常 分散試料である $8: 8$ ゲルとほぼ同じ傾向を示すことがわか る. $8: 8$ ゲルは $6: 6$ ゲルよりもへクトライトとPEOの重 量濃度が多く, 形成されるゲル量が多い。 これにより油滴は より強固に結びつき, Table 2 に示したように降伏応力が増 加する．複屈折は流動によるゲルの配向に起因するが濃度が 変わってもゲルの光弾性係数はあまり変化しないと考えられ る. すなわち, Fig. 8 で測定された領域 Cの複屈折の大きな

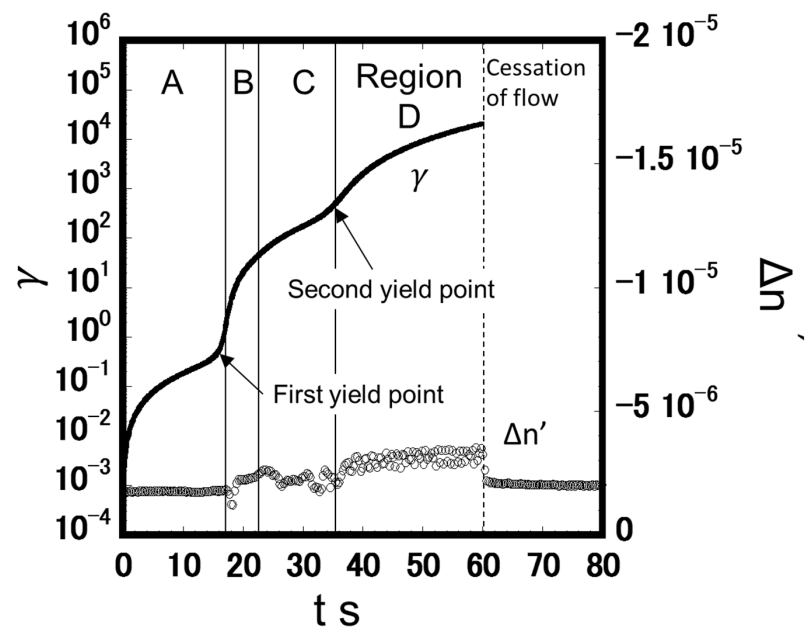

Fig. 7 Rheo-Optic measurement flow chart of $6: 6$ gel.

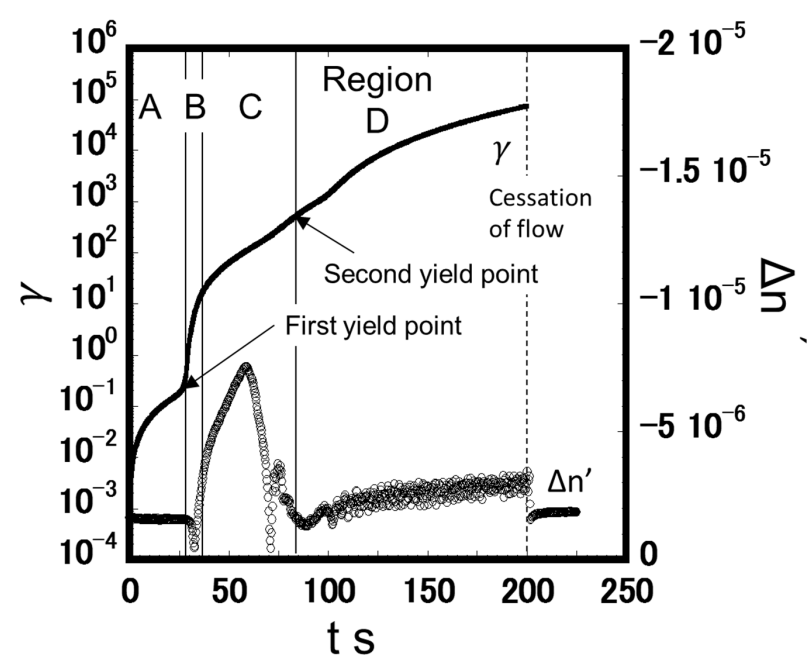

Fig. 8 Rheo-Optic measurement flow chart of $8: 8$ gel.
值は第 1 降伏発生におけるせん断層の形成により局所的に高 いせん断速度が発生していることを意味する. Fig. 9 に示す 高分散化した H8：8 では油滴径が小さく, かつ均一分散化 することで Table 2 に示すように降伏応力は大きく低下する これにより第 1 降伏後のせん断層の挙動はゲルの伸張, 配向 の影響が強くなり複屈折が極端に大きくなったと考えている また, H8：8 ゲルでは第 1 降伏直後の領域 B とその後の領 域 Cで明確に複屈折挙動に違いがあることがわかる。領域 $\mathrm{B}$ はせん断層の発生, 領域 C はせん断層の拡大と流れ場の 発達過程で第 2 降伏に関係する構造がゲルの伸張により誘起 される。これに対して領域 Dではいずれの試料でもほぼ同 等の複屈折が計測された。領域 Dでは厚さ方向にわたって 均一なクエット流れになり，攪拌効果により局所的なゲルの 大変形が発生しなくなると考える。第 1 降伏が発生する前, 油滴はゲルにより拘束され大きな配置の変更が発生しないが, 第 1 降伏後はせん断層で流動が生じる。ここでは油滴は相対 位置が大きく変化するため油滴間のゲルの変形量も大きくな る. 複屈折の大きさの増加はこのためと考えられる。一方, せん断速度がさらに増加するとせん断層の厚みが増加すると ともに第 2 降伏現象を誘起する新しい構造の構築が始まる. これによりゲルの変形量は再び拘束される。領域 Dではせ

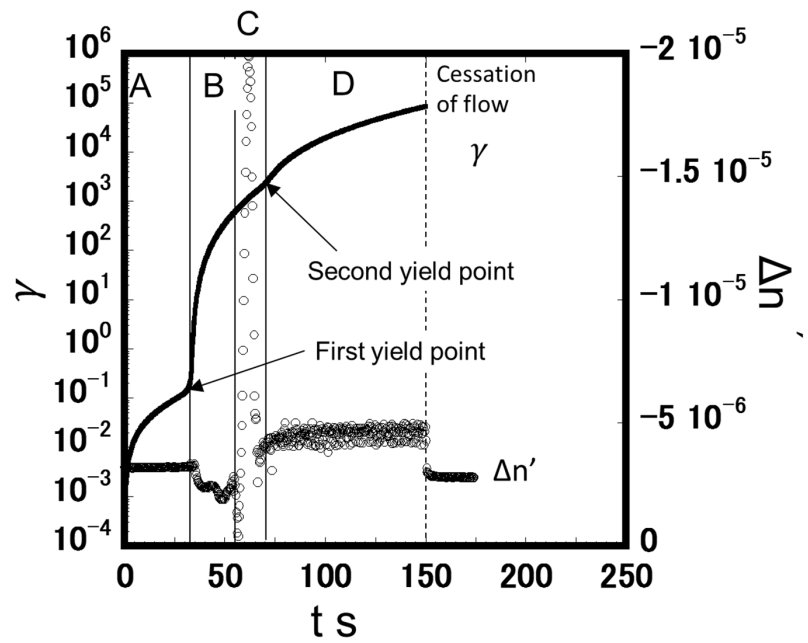

Fig. 9 Rheo-Optic measurement flow chart of H8 : 8 gel.

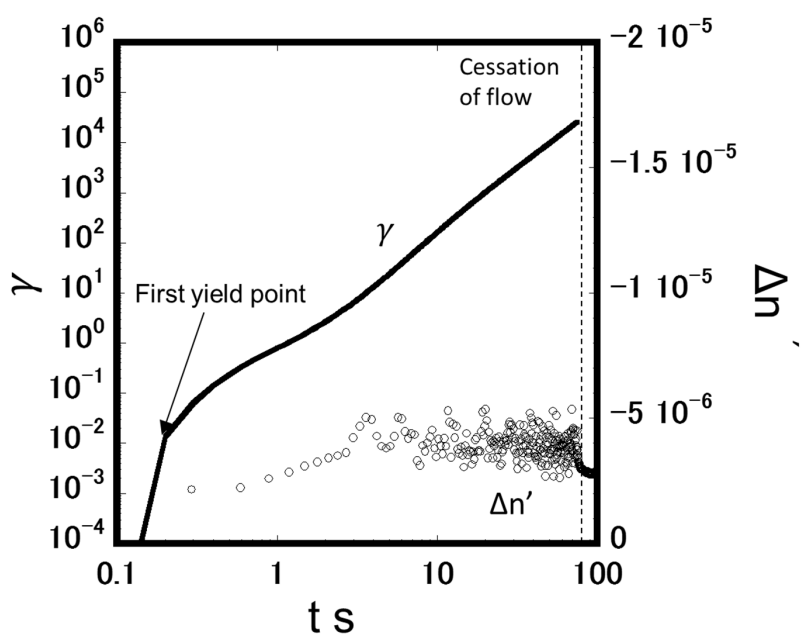

Fig. 10 Rheo-Optic measurement flow chart of $6: 12$ gel. 
ん断応力の増加に伴い複屈折は滑らかに増加し, 流動停止と 同時に急低下する。このときの複屈折の挙動は高分子流体と よく似ている。これより，第 2 降伏発生以後は油滴を結びつ けていた大きな構造は消失し, 少数の油滴がゲルで結びつい た程度の規模になっていると予想される。

6：12 ゲルにおける応力増加試験中のひずみ $\gamma$ と複屈折值 $\Delta n^{\prime}$ の時間的変化を Fig. 10 に示す. $6: 12$ ゲルでは第 1 降伏 発生まで複屈折值 $\Delta n^{\prime}$ は増加し, 降伏後は変動しながらもほ ぼ一定の值を示す。この挙動は $6: 6$ ゲルや $8: 8$ ゲルの第 2 降伏後である領域 Dの挙動に近い.このことから，6：12 ゲ ルでは第 2 降伏挙動は発生しないが, 領域 D に相当する流 動複屈折を伴う構造を形成することがわかる．また，この試 料の複屈折はせん断応力の増加に対して一定值を保ち, Fig. 8 およびFig. 9 に示した結果とは異なる。これは $6: 6$ ゲル や 8：8ゲルでは流動複屈折を伴う構造が流路厚さ方向にわ たり全体に形成され均一な高分子流体に近い挙動となってい るのに対し, $6: 12$ ゲルでは厚さ方向に不均一な状態, たと えばシアバンドが形成されある層で複屈折を伴う構造が形成 されていると考える.このため光学的には領域 D と同じ挙 動が観察されるが, 第 2 降伏に相当する力学的特性が発現し ない. 流動停止後の複屈折減少過程は緩やかに進行すること から架橋構造の弾性的な緩和ではなく, サブミクロンサイズ の油滴を結びつけるゲルなどの微視的構造とそれらが結合し たクラスターとして振る舞う巨視的構造のいずれもが強いせ ん断により破壊され, 流動停止中に再構築する。この双方の 構造の再構築に関係するものと考える.

\section{2 顕微鏡観察による巨視的構造変化と速度解析}

レオ・オプティック測定の結果より, 第 1 , 第 2 降伏の発 生前後において, ゲルを構成する油滴の結合状態が変化し, マクロ的な構造が変化することが見いだされた，そこで，次 に光学顕微鏡により流動中の油滴の運動を直接観察すること を試みる。

Fig. 4 に示した実験装置により, 高分散試料である H8：4 ゲルを観察位置においてせん断速度が $1 \mathrm{~s}^{-1}$ となるよう設定 したステップせん断流動を発生させ, 静止側のガラス面近傍
の液滴挙動を観察した。流路隙間が $0.1 \mathrm{~mm}$ であることから, 下部ガラス板の観察位置での移動速度は $0.1 \mathrm{~mm} / \mathrm{s}$ となる。

Fig. 11 は撮影された動画から所定の時刻における画像を切 り出したものである。流動開始後 1 秒および 2 秒経過後の 2 枚の写真を比較し，どちらの写真にも写っている特定の 1 粒 の液滴が 1 秒間で移動した距離を計測した。流動開始後 1 秒 から 2 秒の時間帯において液滴は $0.10 \mathrm{~mm}$ 移動する。一方, 流動開始後 5 秒から 6 秒の 1 秒間では粒子は $0.01 \mathrm{~mm}$ しか 移動しない，せん断速度が一定であるにもかかわらず，静止 側のガラス面近傍の液滴の移動速度は時間とともに変化する ことがわかった。

そこで，液滴の移動速度をさらに定量的に評価するため, この動画の液滴をトレーサー粒子と見なして PTV 解析して 各液滴の速度ベクトルを求めた。 そして各フレーム間で求め た速度の空間的分布をもとにあるとき刻の平均流速を算出し た. 顕微鏡のピント位置は静止している上部ガラス板近傍に 合わせてあるが，実際にはガラス面近傍だけではなくもう少 し下の層に存在する粒子も可視化されており, PTV解析で もそれらの速度が含まれている。算出された平均流速 $V$ の

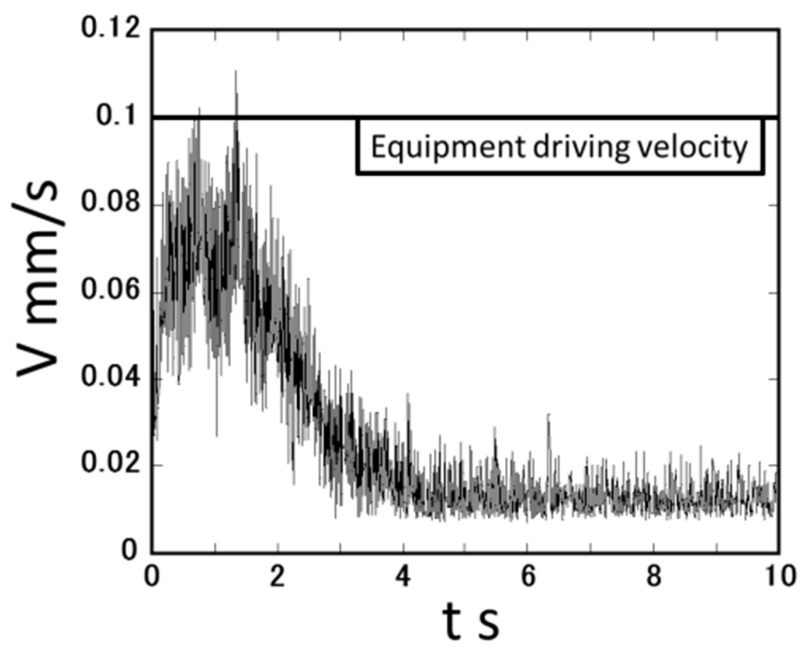

Fig. 12 The moving speed that calculated by the PTV analysis.
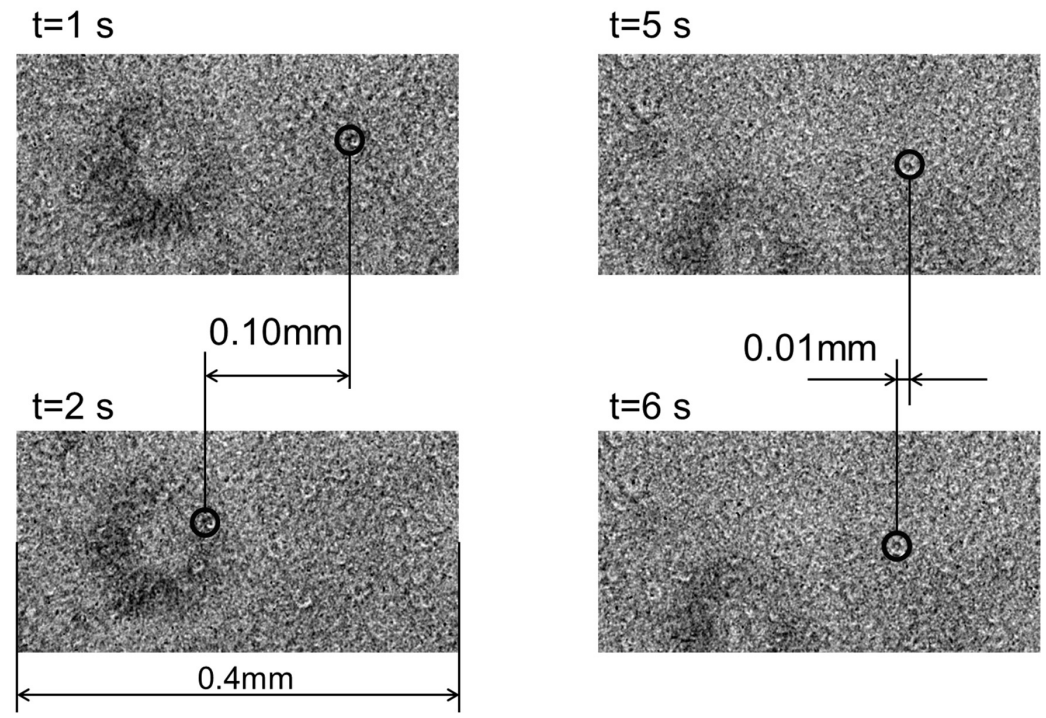

Fig. 11 The Photomicrograph of the sample under the step shear $\left(\dot{\gamma}=1 s^{-1}\right)$. 
時間に対する変化を Fig. 12 に示す。流動開始から 1.5 秒く らいまでは静止壁面側近傍の液滴が下面の回転壁面に近い速 度で移動している。これは静止円板のごく近傍にせん断層が 形成され，それよりも下部の試料は下部円板とほぼ同じ速度 で固まりとして回転していることを示す。1.5 秒を過ぎると 急激に速度は低下し 4 秒後にはほぼゼロに近づく。これはせ ん断層が拡大し次第にクエット流れに近づいていることを表 している. 最終的には静止している上部円板近傍では粒子速 度はゼロに近くなる。このように, せん断層の発生と流動時 間の経過によるせん断層の厚さの増加, 速度分布の発達の様 子を定量的に求めることができた。 また，減速が開始するひ ずみはおよそ $\gamma=3$ であり，これは応力ひずみ線図における 領域 C に相当する。このことから, 領域 Cにおいて液滴の 移動速度が劇的に減速する領域が局所的に存在することが予 想される。

\section{3 応力増加試験中の外観観察と輪郭線の変化}

液滴の動きを観察することで，平行円板間の隙間方向にお いてせん断層の形成や栓流のような固まりでの流動, そして 時間経過による液滴を結ぶ拘束力が低下して流動的挙動，す なわち液滴が自由に移動できる状態に変化する様子が観察で きた。ここから，液滴がゲルにより結合されたマクロ的な構 造は流動によって破壊されること, その現象が局所的に発生 することが示唆された。 そこで，今度はゲルで結合された液 滴のマクロ的な構造が流路半径方向にわたって局所的に発生 する可能性を考え，流れ場全体を一望する可視化を行い，流 路内の試料の輪郭，すなわち気液界面の形状を調べる.

Fig. 13に8：16 ゲルに対して実施した応力増加試験より 得られた応力ひずみ線図と外観観察で得られた動画から任意 の時点を切り出した写真を示す。第 2 降伏現象を発生しない 8：16 ゲルでは応力増加試験中の試料の輪郭線の形状は, 測 定開始前の状態である円形を保ちつづける。一方, 第 2 降伏

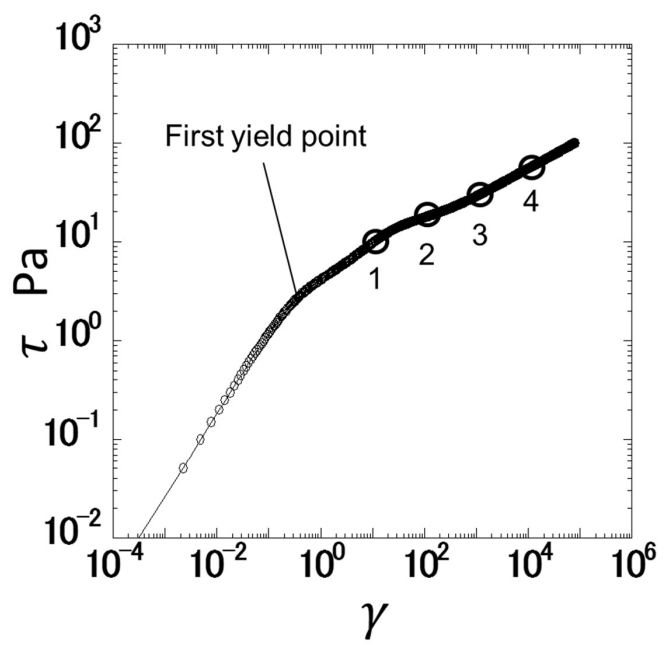

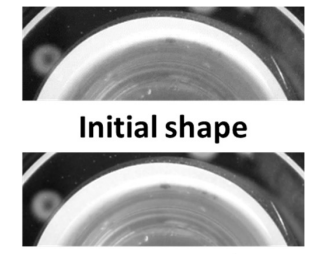

1. $\gamma=10^{1}$

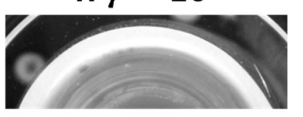

2. $\gamma=10^{2}$

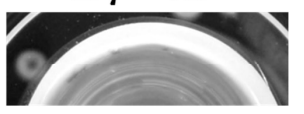

3. $\gamma=10^{3}$

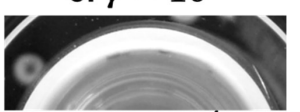

4. $\gamma=10^{4}$

Fig. 13 The Stress-Strain curve and transformation of the contour line of the sample under the shear ramp test (only the first yield behavior).
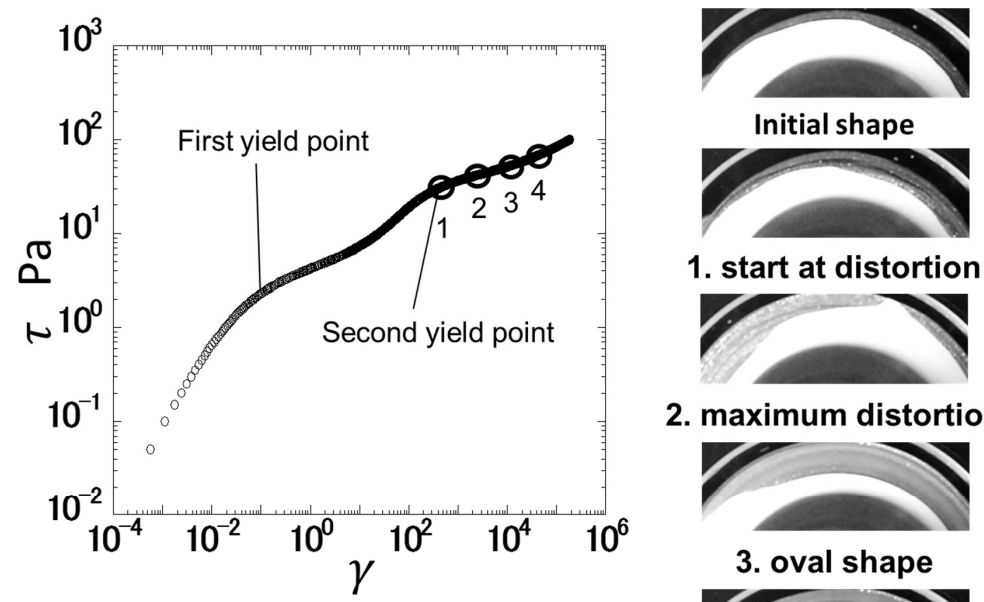

2. maximum distortion

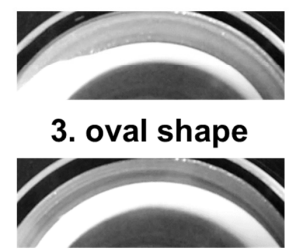

4. circular shape

Fig. 14 The Stress-Strain curve and transformation of the contour line of the sample under the shear ramp test. 
現象が発生する $8: 8$ ゲルの応力ひずみ線図と外観観察の結 果を Fig. 14 に示す。測定開始前, 輪郭線の形状は Fig. 14 の いちばん上の写真からわかるように 8：16 ゲルと同じく円形 である. しかし, 応力が第 2 降伏点に到達すると, Fig. 14 の写真 1 で示すように試料の輪郭線の形状がゆがみはじめ, やがて写真 2 で示すように大きく変形する. 第 2 降伏点の後, 変形した輪郭線は写真 3 のゆがんだ状態から写真 4 のように 円形へと戻っていく. Fig. 14 の写真 2 からわかるように試 料の輪郭線が円形からゆがむ理由は輪郭線近くの試料が同じ 半径の円周上で均一ではなく, 局所的に粘度が増加する場合 に発生する，数ミリ程度の直径を持つ微小領域が急に増粘す ることで同心状の低粘度の流体はそれを避けるように流動し, 輪郭線をゆがませる。この局所的な増粘領域は第 2 降伏を誘 起する構造と直接的な関係があると考えている。第 2 降伏が 発生後も局所的な増粘領域の形成は続くが, 写真 4 で示す高 せん断応力域に達すると局所的な増粘領域は発生しなくなる. 短時間で試料外周形状の大きなゆがみが解消し円周状に変化 することから, 試料の外周部から中心方向へと向かう締め付 け力が作用していることがわかる.このような中心方向へと 向かう強い締め付け力は法線応力効果によって発生する「た が力」であると考えられ, 試料にはずり弾性が発生している ことを示している. つまり, 第 2 降伏以後の高せん断応力域 においてはずり弾性による第 1 法線応力差が発生しているこ とが示された.これはFig. 7, Fig. 8 で示したレオ・オプ ティック測定において領域 D で高分子流体とよく似た流動 複屈折が発生したことと合致する.

このような輪郭線の変形と関係するレオロジー特性を明ら かとするため, 以下の手順で動的粘弾性試験を実施した.

（1）すべての試験における初期状態を一定に保つため, 初期 流動として $50 \mathrm{~s}^{-1}$ のステップせん断流動を 60 秒間与える.

（2）せん断応力をゼロから一定の応力増加率を保って増加さ せる応力増加試験を行う.（3）所定の最大応力に達したとこ ろで流動を停止し, そのまま連続してひずみ $\gamma=0.1$, 角周波 数 $\omega=0.1 \sim 100 \mathrm{rad} / \mathrm{s}$ で動的粘弾性試験を行う. ここで, 流 動を停止する最大印加応力は $0,5,20,100 \mathrm{~Pa}$ の 4 通りで, これらの応力はそれぞれ Fig. 2 で示した領域 A, B, C, D に相当する.この試験より得られた各領域まで流動させた $8: 8$ ゲルにおける損失正接 $\tan \delta$ を Fig. 15 に示す. 損失正

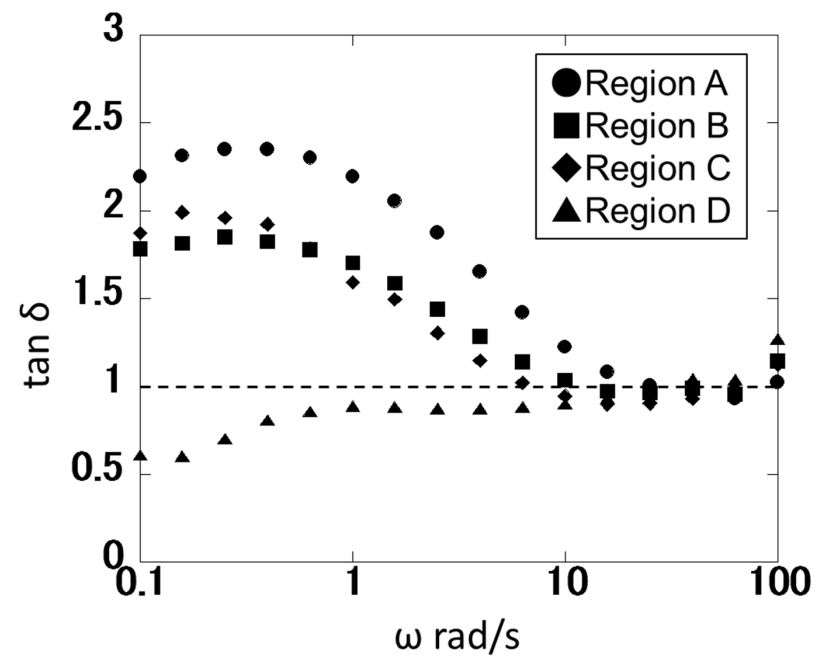

Fig. 15 Results of a dynamic viscoelastic test for each region.
接 $\tan \delta$ は貯蔵弾性率 $\mathrm{G}^{\prime}$ と損失弾性率 $\mathrm{G}^{\prime \prime}$ より, $\tan \delta=G^{\prime \prime} / G^{\prime}$ から求められる。高角周波数側はどの領域も同様の結果を示 しているが，低角周波数側に注目すると領域 A, B , Cでは 損失正接の值が 1 を上回り粘性が支配的な性質を示すのに対 し, 領域 Dのみ 1 を下回り弾性が支配的な性質を示すこと がわかる。すなわち，外観観察でみられた変形した外形線が 再び円形に戻る挙動から予測されたように, 領域 D に達す ると試料はそれまでよりも強い弾性を発現することがレオロ ジー測定からも明らかとなった。流動複屈折測定の結果と合 わせて, この弾性力は高分子と同ような絡み合い系により発 生すると予想され, 領域 D では油滴がゲルにより鎖状に連 なる構造となっていることが予想できる．第 2 降伏後に弾性 が支配的となることや, 第 2 降伏付近で試料の外形線が大き くゆがむなどの挙動は試料の組成ではなく, 降伏挙動の発生 に関わる構造による影響だと予想できるため, 配合割合や通 常分散・高分散にかかわらず第 2 降伏挙動が発生する試料で は同様の傾向がみられると考えられる。第 1 降伏発生前であ る領域 A では, 応力増加試験および流動複屈折測定の結果 から弾性が支配的である。この動的粘弾性測定では測定時間 短縮のため印加するひずみを大きくしており，これにより測 定中に降伏が発生し粘性が支配的になったと考えられる。す なわち, 領域 Aに拈ける結果は不正確であり考察の対象と はならない.

\section{4. 結 言}

粘土を含有するコロイドゲルにおける降伏特性の発生メカ ニズムを含む流動挙動に関して, 油滴が結びついたマクロ的 構造と降伏挙動の関係について注目し, 流動複屈折測定, 外 観観察および顕微鏡観察により降伏によるマクロ構造の変化 を実験的に検討した。以下に得られた結果をまとめる.

コロイドゲルは静置時には油滴がゲルにより結合し互いの 位置関係を保つようなマクロ的な構造を形成する。第 1 降伏 挙動では流路幅方向においてせん断層が発生し, 流動ととも にせん断層が厚くなり最終的には油滴がバラバラに流動する 状態に達する。ささらにせん断応力 · せん断速度が増加すると 第 2 降伏前後の流れにおいてはそれまでとは異なり高分子的 な流動複屈折が発生した. このとき, 平行円板間の試料の外 周付近では, 周方向にわたって均一ではなく局所的な増粘領 域が形成され輪郭線に大きなゆがみが発生する。さらにせん 断応力を増加させるとやがて輪郭線は円形に戻ることから高 応力域では円板の中心方向へと向かう力，つまり「たが力」 の発生が確認された。たが力はずり弾性による法線応力効果 に起因するため, この状態においてゲルには絡み合いによる 弾性力が作用していることが明らかとなった。この状態の試 料に対して動的粘弾性試験を行ったところ損失正接 $\tan \delta$ が 1 以下で弾性力が支配的な状態であることがわかった．流動 複屈折, 輪郭線の挙動, 動的粘弾性の結果のいずれもが領域 Dにおける弾性力の発生を示しており，第２降伏を誘起する 構造が高分子に似た絡み合いを形成するものであると予想さ れる。

\section{REFERENCES}

1) Nishihama S, Nendo Kagaku, 44, 143-149, (2005). 
2) The Clay Science Society of Japan, "Handbook of Clay and Clay Minerals", 3rd ed, (2009), Gihodo Shuppan Co., Ltd, Tokyo (in Japanese).

3) Osada Y, Kajiwara K, “Gels Handbook”, 2nd ed, (2003), NST Inc, Tokyo (in Japanese).

4) Arakawa M, Nendo Kagaku, 10, 8-14, (1970).

5) Nikko Chemicals Co. Ltd., Nippon Surfactant Indusiries Co Ltd., Toshiki Pigment Co., Ltd, "Keshouhin Handbook", (1996), Chuo Printing Co., Ltd, Niigata (in Japanese).

6) Hukui H, "Tokoton Yasashii Keshouhin No Hon", (2009), The Nikkan Kogyo Shinbun Ltd, Tokyo (in Japanese).

7) Sekine T, Takahashi T, Nendo Kagaku, 53, 94-102, (2015).

8) Conrad JC, Lewins JA, Langmuir, 24, 7628-7634, (2008).

9) Pérez-González J, López-Durán JJ, Marín-Santibáñez, BM, Rodríguez-González F, Rheol Acta, 51, 937-946, (2012).

10) Hyun K, Kim SH, Ahn KH, Lee SJ, J. Non-Newtonian Fluid Mech, 107, 51-65, (2002).
11) Clasen C, Rheol Acta, 51, 883-890, (2012).

12) Derakhshandeh B, Vlassopoulos D, Hatzikiriakos SG, Rheol Acta, 51, 201-214, (2012).

13) Wulff-Pérez M, Martín-Rodríguez A, Gálvez-Ruiz MJ, de Vicente J, Colloid Polym Sci, 291, 709-716, (2013).

14) Hou L, Rheol Acta, 51, 603-607, (2012).

15) Buscall R, Scales PJ, Stickland AD, Teo HE, Lester DR., J. Non-Newtonian Fluid Mech, 221, 40-54, (2015).

16) Stickland AD, Kumar A, Kusuma TE, Scales PJ, Tindley A, Biggs S, Buscall R, Rheol Acta, 54, 337-352, (2015).

17) Nabata Y, Riron Ouyou Rikigaku Kouenkai Ronbunshu, 57, 70, (2008).

18) Nabata Y, Suzuki K, Yoshida K, Namiki N, Shibata M, Nihon Rheoloji Gakkaishi (J Soc Rhol Jpn), 35, 79-84, (2007).

19) Fuller GG, "Optical Rheometry of Complex Fluids", (1995), Oxford University Press, NY. 